\title{
The Road to an Improved Tax Curriculum in South African Schools
}

\section{Ruanda Oberholzer}

Economic and Management Science Faculty, University of Pretoria

\section{Martelize Nel}

Economic and Management Science Faculty, University of Pretoria

\begin{abstract}
Since the vast number of scholars will be the taxpayers of the future, implementing tax education at school level should greatly enhance the success of the tax system. This will ensure that the majority of South Africans will have the opportunity to receive a basic understanding of tax and be more aware of what may be expected of them in the future. This paper investigates the existing level and adequacy of tax education in South African schools. A number of shortcomings within the current school tax curriculum in South Africa have been identified, for example use of wrong terminology and the absence of flow charts and case studies. In addition, it has been found that educators do not receive proper training on the content of the curriculum, with no assistance available from the South African Revenue Service (SARS) in this regard. It is suggested that SARS and the Department of Education (DoE) work in collaboration to improve the current tax curriculum, which will potentially make an increasing percentage of South Africans responsible taxpayers, who properly understand their obligation to contribute to and improve the tax compliance culture within this country, one of the main visions of the South African Revenue Service.
\end{abstract}

Keywords: Tax curriculum; Taxpayers' education; Vision of SARS.

\section{Introduction}

The South African government raises taxes to enable the government to deliver a number of services not provided by the private sector. This government expenditure is funded mainly by means of revenue generated by the South African Revenue Services (SARS) from levying taxes (Mohr, Van der Merwe, Botha \& Inggs, 1988:79-81). A combination of direct and indirect taxes are used (Huxham \& Haupt, 2005:1), the former payable as income tax, employees' tax and provisional tax (SARS, 1998:2), the latter as payments on goods bought by consumers, for example, Value Added Tax (VAT) and Customs and Duties (SARS, 1998:2). Apparent from Table 1, during 2001, $58.4 \%$ of the total available labour force were potential taxpayers (Statistics South Africa, 2001a:1), and $41.6 \%$ of the available labour force were unemployed. These individuals could, however, potentially enter the job market if more job opportunities are created, one of the main focus areas of government. Hence, a larger number of South Africans might be liable for income tax at some stage of their economically active life. 


\begin{tabular}{lll}
\hline $\begin{array}{l}\text { Labour market } \\
\text { status }\end{array}$ & $\begin{array}{l}\text { Number of } \\
\text { people }\end{array}$ & $\begin{array}{l}\text { Percentage of total } \\
\text { labour force }\end{array}$ \\
\hline Employed & 9583762 & $58.4 \%$ \\
Unemployed & 6824075 & $41.6 \%$ \\
Total labour force & $\mathbf{1 6 4 0 7 8 3 7}$ & $\mathbf{1 0 0 \%}$ \\
\multicolumn{2}{l}{ Statistics South Africa (2001a:1) }
\end{tabular}

A large percentage of taxpayers consist of salary earners, all of whom are liable for employees' tax, which is deducted from the remuneration of salary earners on a monthly basis in terms of the Fourth Schedule of the Income Tax Act 58 of 1962 (the Act). The purpose of this schedule is to ensure that the taxpayer's income tax is settled at the same time that it is earned (SARS, 1999:7). At the end of each tax year, assessments are raised on the income of salary earners, the burden of proof lying with the taxpayer, to indicate whether certain deductions or exemptions are to be taxed or not (Section 82 of the Act).

Peters (1991:188) found that citizens do, in general, enjoy the benefits they receive from government and tend to be much more willing to pay taxes when reminded of these benefits received as a consequence of doing so. Lewis (1982:59) additionally highlights that fiscal ignorance is a major contributor to the formation of negative feelings towards taxation. Residents, not only lawyers and accountants, could benefit from having the knowledge of basic tax concepts in order to manage their affairs and understand national issues (Flesher \& Rescho, 1986:56). Knowing about taxes should also be regarded as an important life skill (Australian Tax Office, 1998:1). Feltham (1996:31) points out that across the globe tax education is based on many different visions, but all share two primary elements: knowledge of institutional tax and tax planning or decision-making. It is the vision of SARS to become an innovative revenue and customs agency that enhances economic growth and social development (SARS, 2002:1).

In ten years of democracy, SARS has striven continuously to broaden the tax-base, improve its service levels to taxpayers and pursue enforcement initiatives that contribute directly to increased revenue yield, which will finance government's developmental agenda. SARS regards as one the crucial challenges to government as being the creation of the right type of corporate and individual citizenship and an understanding of their obligation to contribute to an improving tax compliance culture, and display of principled opposition to any form of criminality, including tax evasion (SARS, 2004:2).

During the 2003 to 2004 financial year, dispute-resolution mechanisms were launched, as were improvements in SARS's anti-evasion drive, the free e-filing facility to businesses, and a comprehensive drive to improve levels of taxpayer filing (SARS, 2004:2). Electronic brochures and other information were made available on SARS's website (sars.gov.za), including guides for completing forms and for small businesses. However, since only $8.6 \%$ of households in South Africa have computers in working condition (Statistics South Africa, 2001b:7) it is likely that only a small percentage of individuals are actually exposed to such information through this medium. 
Other initiatives taken by the SARS (2004:3) are to broaden the tax base, emphasise taxpayer education and assistance with tax returns, reduce the error rate on those returns and simplify the processes. Focus was to be placed on single registration of taxpayers for all tax types, and scanners introduced in ports and at border posts to ensure accurate declaration of goods. It is clear that the SARS understands the need for tax education, but despite ad hoc education workshops, advertisements in newspapers and school visits focusing on certain topics, during an interview with the person responsible for taxpayers' education, it became evident that no formal policy on this existed (Phillips, 2004).

In a survey undertaken by Oberholzer (2005:249-275), that concerns the perceptions of taxation held by previously disadvantaged South Africans, it was found that there was a need for improved knowledge regarding tax systems, the implementation of these systems and the utilisation of revenue received from taxation. The study further revealed that, although the majority of previously disadvantaged South Africans included in the study are paying taxes, they are unable to list the different types without assistance. The author concluded the study by stating that the government has an opportunity to empower not only previously disadvantaged citizens, but all, by providing them with information regarding taxation. A suggested starting point in tax education is to include programmes on taxation in schools, as today's children are the future taxpayers.

\section{Research aim, objectives and method}

The purpose of this paper is to determine whether the inclusion of taxation as part of the curriculum at school level in South Africa is viable. It evaluates the tax education programme at school level in the United States of America (USA) in order to compare it with the current situation in South Africa, the reason being that the information regarding this programme is readily available, albeit the USA has one of the most developed tax education systems in the world. Finally, the existing level and adequacy of tax education in South African schools are investigated by evaluating the current curriculum in place. The components of a good curriculum are explored in order to achieve this objective.

Both a comparative and a descriptive study were employed as the research method for this study. The Revised National Curriculum Statement (RNCS) Grades R-9 issued in April 2002 by the Department of Education (DoE) provides guidelines on what should be taught from Grades $\mathrm{R}$ (the reception year before Grade 1) to 9, the required outcomes (or what is expected of learners in each year and the standards to be used to assess whether learners have achieved these outcomes. Eight learning area statements form the foundation of this RNCS, of which Economic and Management Sciences (EMS) is the one that deals with the efficient and effective use of different types of private, public or collective resources in satisfying people's needs and wants, while reflecting critically on the impact of resource exploitation on the environment and people. The effect of the national budget on the economy (e.g. taxation and government expenditure) is covered in the EMS learning area statement. Provincial educational departments are currently implementing the revised curriculum in stages, having started in Grade R, in 2004. 
The teacher's guide for the development of learning programmes for EMS stipulates that teachers will have to be familiar with the resources needed and resources available as they develop their programmes (DoE, 2003:7). This study is only an exploratory study and, therefore, does not attempt to evaluate all the currently available resources on the EMS learning area statement. In addition, only the senior phase (specifically grade 9) of the EMS learning area statement will be investigated.

\section{Suitable phase in the South African education cycle to introduce tax as part of the curriculum}

Education is an aspect of socialization and a lifelong process of learning the attitudes, values and behaviour appropriate to members of a particular culture that has become a vast and complex social institution that prepares the citizens of the world for various roles demanded of them by other social institutions, such as the family, government and the economy. One of its basic functions is the transmission of knowledge that sorts people into appropriate levels and courses of study that will prepare them for appropriate positions within the labour force (Schaefer, 1989:442-448). Scholars are additionally introduced to standards of proper conduct in public life which may be quite different from the rules of behaviour accepted in their families. This prepares the younger generation to lead productive and orderly lives as adults by introducing them to the norms, values and sanctions of a larger society. This could involve, for example, paying taxes as well as abiding by tax laws. They learn various skills and values which will be essential in their future positions within the labour force which can stimulate or bring about desired social change (Schaefer, 1989:445-446).

As indicated in Table 2, over 12.5 million learners between the age of 5 and 24 attended school in South Africa during 2001 (Statistics South Africa, 2001a:1). A further 5.5 million children of schoolgoing age are not attending any type of educational institution, and over half a million children attend pre-school. Only a small number $(60,271)$ attend either an adult education centre or some other form of educational institution, and only about 500,000 students attend a tertiary institution (a college, technikon or university) (Statistics South Africa, 2001a:1).

Table 2: Number of people aged 5 to 24 attending an educational institution in South Africa, 2001

\begin{tabular}{ll}
\hline Institution & Number of people \\
\hline None & 5463873 \\
Pre-school & 575936 \\
School & 12584825 \\
College & 191230 \\
Technikon & 145977 \\
University & 169604 \\
Adult education centre & 26480 \\
Other 33 791 & \\
Total $\quad \mathbf{1 9} \mathbf{1 9 1} \mathbf{7 1 6}$ & \\
Statistics South Africa (2001a:1)
\end{tabular}


When considering all people above the age of 20 in South Africa, 31\% have attended secondary school and $20.4 \%$ have graduated from high school (Statistics South Africa, 2001a:1) (see Table $3)$.

Table 3: Level of education of people above the age of 20 in South Africa, 2001

\begin{tabular}{lll}
\hline $\begin{array}{l}\text { Highest level of } \\
\text { education }\end{array}$ & $\begin{array}{l}\text { Number of } \\
\text { people }\end{array}$ & $\begin{array}{l}\text { Percentage } \\
\text { of total }\end{array}$ \\
\hline No schooling & 4567497 & $17.9 \%$ \\
Some primary schooling & 4083742 & $16.0 \%$ \\
Complete primary schooling & 1623467 & $6.4 \%$ \\
Some secondary schooling & 7846125 & $30.8 \%$ \\
Grade 12 & 5200602 & $20.4 \%$ \\
Tertiary education & 2151336 & $8.4 \%$ \\
Total & $\mathbf{2 5 4 7 2 ~ 7 6 9}$ & $\mathbf{1 0 0 \%}$
\end{tabular}

Adapted from Statistics South Africa (2001a:1)

It is clear from Table 3 that of all the persons in South Africa between the ages of 5 and 24 years attending some form of educational institution in 2001, 92\% were attending school (see Figure 1). Even though only $20.4 \%$ of people above the age of 20 have graduated from high school, a significant proportion (31\%) have attended secondary school. This indicates that tax education could be implemented at the early secondary level.

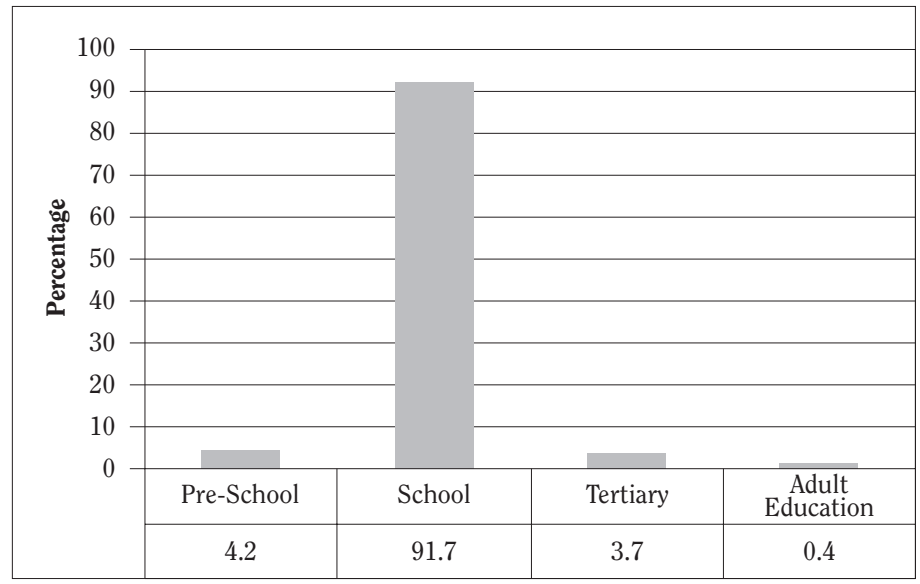

Adapted from Statistics South Africa (2001a:1)

Figure 1: Percentage of students aged 5 to 24 attending an educational institution, 2001

From the above, it is evident that tax education should be implemented at the early secondary level. It is suggested that, since the vast number of school-going children are the taxpayers of the future, implementing tax education at school level should have the best chance of success. This 
will ensure that a large percentage of all South Africans will have the opportunity to receive some form of tax training.

\section{The tax education programme at school level in the United States of America}

Hite and Hasseldine (2001:10-11) claim that the USA arguably has one of the most developed tax education systems in the world, largely due to the work of the American Taxation Association (ATA). Part of their services is to assist tax educators in teaching, as well as in research. The ATA has a Teaching Resources Committee that is currently producing a monograph on tax teaching. This tax education system has developed over years of sharing research and experiences among a community of learners.

The American Internal Revenue Service (IRS) has an educational site for high school and other learners on its website (www.irs.gov), called "Understanding Taxes". Three interactive educational kits include lessons on the nation's history of taxation, tax return preparation and the economics of taxation. These help students to understand the basic rationale, nature and consequences of taxes (IRS, 2004a:1). The stated objectives of these lessons are to enable students to describe why governments need revenue to provide goods and services; to identify taxes as an important source of governmental revenue; and to explain how taxes transfer the use of resources from the private sector to the government (IRS, 2004a:1). This lesson could be used in any one of the following curriculum areas: Civics or Government, Economics, Technology, History or Social Studies.

Fifty percent of public school teachers in 1999 reported that they had used computers or the Internet for instruction during class time and/or that they had assigned their students work that involvesd research using the Internet (Kleiner, Lewis \& Greene, 2003:13). These authors continue to state that $87 \%$ of public schools with Internet access offered professional development to teachers in their school on how to integrate the use of the Internet into the curriculum. The "understanding taxes" programme is available online or, for more traditional instruction, as a package of downloadable print resources. These materials can be used as a complete unit or can be presented as individual activities or lessons. The content of this programme consists of a set of 36 student lessons divided into two distinct areas, namely the "Hows of taxes" that provide tax application, and the "Whys of taxes" that examine the theory and history behind American taxes. A very important feature is the lesson plan outline for teacher instruction that gives information to teachers on how to teach tax and background information. This eliminates the need for extensive outside research for tax materials. As a guideline it is indicated that one to three class periods should be spent per lesson (IRS, 2004a:1).

In the section "The Hows of taxes", 12 modules offer a step-by-step approach to tax preparation education., including Payroll Taxes and Federal Income Tax Withholding; Wage and Tip Income; Interest Income; Dependents; Filing Status; Exemptions; Standard Deduction; Tax Credit for Child and Dependent Care Expenses; Earned Income Credit; Refund, Amount Due, and Record Keeping; Electronic Tax Return Preparation and Transmission; and Self-Employment Income and the SelfEmployment Tax. Under the "Whys of taxes", information is divided into six themes, with each theme divided into lessons (IRS, 2004a:1): Your Role as a Taxpayer; Taxes in U.S. History; Fairness in Taxes; What is Taxed and Why; Impact of Taxes; and Understanding the IRS. 
In the programme, each lesson provides background information and key terms and definitions, along with an entry point to a variety of interactive exercises, such as tax tutorials, simulations, and more than 75 online activities (IRS, 2004a:1). This modular tax programme is very detailed, however, one concern is that there is no indication of how many learners are actually reached. For instance, and of relevance to South Africa, for the above mentioned to be viable for students, they need access to computers and the Internet.

DeBell and Chapman (2003:3) have established that in the USA, $90 \%$ of 5 to 17 year-olds ( 47 million persons) use computers and about 59\% (31 million persons) use the Internet. Among high-school age youths (ages 15 to 17), more than $90 \%$ use computers and at least three-quarters the Internet. Home and schools are the primary locations for computer-use, with a greater percentage at the former. Kleiner, Lewis and Green (2003:3-9) state that, in 2002, 99\% of public schools in the USA had access to the Internet and that access expanded in instructional rooms, notably classrooms, computer and other laboratories, and library/media centres, from 3\% in 1994 to $77 \%$ in 2000 and $92 \%$ in 2002 . The ratio of students to instructional computers with Internet access was 4.8 to 1. Public schools with Internet access reported that they made it available to students outside regular school hours, and $96 \%$ of schools made their computers available after school, $74 \%$ before school and six-percent on weekends. Seven percent of public schools provided hand-held computers to students or teachers for instructional purposes. De Bell and Chapman (2003:29) explain that children and adolescents use the Internet for activities such as communicating, finding information, having fun, doing homework and completing school assignments. $42 \%$ of all youths in the age range from five to 17 utilise the Internet for schoolwork. It therefore appears that the majority of high school students do have access to the "understanding taxes" programme.

The IRS has also developed a Volunteer Income Assistance (VITAe ${ }^{3}$ ) programme for schools, with the emphasis on e-file, education and voluntary experience. During the tax filing season, schools host a VITAe ${ }^{3}$ site. These sites offer assistance in preparing basic income tax returns for individuals with a low to moderate income, individuals with disabilities, non-English speaking taxpayers and the elderly (IRS, 2004b:1). Students and other volunteers are trained to help people to prepare these basic tax returns. The volunteers and students are trained in three different areas: tax, software and people skills. The VITAe ${ }^{3}$ programme can also be incorporated in the school curriculum (IRS, 2004b:1).

From the above, it is clear that the "understanding taxes" programme on the IRS-website that is specially developed for high school and other students is very detailed. The tax information that is provided presents students with background information on tax laws and knowledge on key terms, basic concepts and definitions. Each of the themes allows students to gain insight into how the American tax system was developed and how tax influences citizens. The content of the programme is divided into 36 student lessons and the recommended time allocated for each lesson is between 1 and 3 periods per lesson. Although it is not a compulsory program, it is assumed that with the high percentage of students having Internet access, this programme is very successful.

In the next section of this paper the components of a good curriculum is investigated in order to evaluate the existing level and adequacy of tax education in South African schools. 


\section{The Components of a good curriculum}

According to Hanno (1999:323-335), students are diverse and respond differently to different teaching and examination approaches. Bonner (1999) concurs and argues that the choice of teaching methods should be based on the type of learning objective. This is further supported by Hite and Hasseldine (2001:8) and thus implies that approaches may also vary in their effectiveness for different types of educators. A balance needs to be found between these three factors in order to find the best teaching method for a given situation. Bearing in mind that the material could be new to both the educators and the learners, sources and resources will be needed. Flesher \& Rescho (1986:55) state that, generally, the method of conducting a basic tax course required students to memorize rules and methods of calculations, and that learning could have been more effectively achieved had tax concepts been embodied in the tax course along with the tax rules and regulations.

Gore and Wong-on-Wing (1998:117-126) suggest that tax skills (procedural knowledge) should be taught, as opposed to detailed tax rules and facts (declarative knowledge). Psybox: a Web dictionary of Psychology (2006) defines procedural knowledge as "knowing "how" (e.g., how to bake a cake), as opposed to knowing "that" (e.g., that Paris is the capital of France), which is referred to as "declarative knowledge". Gore and Wong-on-Wing (1998:117-126) propose that when teaching tax classes, educators should consider the following four steps:

- instruction is organized around specific tax skills;

- a task analysis is completed for each skill;

- instruction is example-based; and

- learners are given practice on holistic real-world problems.

These authors further state that this skill acquisition is not inconsistent with existing educational methods designed to improve the development of declarative knowledge, but rather highlights the link between declarative and procedural knowledge. They maintain this link is the knowledge compilation (body of knowledge), which is done by practising with real problems and then solving these by analogy to the examples given.

A new approach to teaching tax (Jones \& Duncan, 1995:100-101) consists of three principles, the first of which is that learners should recognize that tax law is an integrated component of a complex business environment. The second principle considers that students need to comprehend the body of tax law as an organic whole and not as a fragmented collection of isolated rules and regulations. They should learn how the general rules apply to all taxpaying entities before they are taught how the law applies differentially to certain taxpayers. The third principle is that students who really learn fundamental concepts will have a permanent frame of reference into which they can integrate the constant changes in the technicalities of tax law.

Using case studies in teaching tax is central to understanding the practical implications of tax concepts. Case studies can be presented either in a stand-alone fashion or as part of an integrated problem that ends with the completion of the individual personal tax return (Oppenheimer, 1997:323). The inclusion of case studies challenges students to think about the implications of the 
tax law, rather than simply memorizing rules. Case studies also work well as outside writing assignments, providing an opportunity for students to improve their written communication skills (Nichols, Everett \& Boley, 1999:118).

After the curriculum objectives have been established, the next step is identifying the extent and level of technical detail that should be covered in the course and those concepts that are, for one reason or another, to be excluded. Jones and Duncan (1995:102-103) suggest that the nature of the concepts, their usefulness to the students, as well as whether the concepts add to the students' understanding of the deep structure of the tax laws, should be used as guidelines. They state that certain concepts simply have to be covered in detail, despite their complexity. On the other hand, for certain concepts, it is only necessary that a middle ground be established that allows a lower level of inclusion, sufficient to ensure identification.

Jones and Duncan (1995:103) continue by stating that a lack of stability with regard to changing laws is an attribute that should warrant a decision to exclude or limit exposure to concepts, but frequently applied concepts relating to a number of regulations should merit inclusion. Therefore, if certain regulations in the tax laws are frequently changed, the curriculum should omit them, but common and key concepts and issues should be included. When any new tax legislation is passed, the challenge facing an educator is that the new tax law must be learned and understood (Nichols, Everett \& Boley, 1999:118). The course material must, therefore, be concise and up-todate, or must be easy updateable. The text should also be in an easy-to-teach format so that the educator is able to be in control of the nature of the material.

\section{Existing level and adequacy of tax education in South Africa schools}

The EMS learning area statement is compulsory for school learners. In particular, this learning area deals with the nature, processes and production of goods and services; the South African economy and socio-economic systems in different countries; financial management and planning skills for private, public or collective ownership; and entrepreneurial skills and knowledge needed to manage self and the environment effectively (DoE, 2002:4). The introduction of this learning area statement forms part of the DoE's attempt to reach the objective of providing strategic direction in the development of an effective higher education system and to manage the government's responsibilities for the regulation of the higher education system (DoE, 2004:1).

The EMS learning area statement has several unique features which are consolidated into four learning outcomes, namely the economic cycle, sustainable growth and development, managerial, consumer and financial knowledge and skills and entrepreneurial knowledge and skills (DoE, 2002:4-6). The learning outcome "the economic cycle" stipulates that the learner will be able to demonstrate knowledge and understanding of the economic cycle within the context of "the economic problem". One of the assessment standards of "the economic cycle" in the Senior Phase is for a Grade 9 school learner to be able to discuss the effect of the national budget on the economy (e.g. taxation and expenditure on education, social welfare, health and security). According to the teacher's guide for the development of learning programmes for EMS, the respective teacher is responsible for implementing this assessment standard by means of a learning programme. The 
learning programme, in turn, is translated into a yearlong, grade-specific work schedule and shorter activity-long lesson plan (DoE, 2003:2).

According to a teacher of the EMS learning area statement, Weirich (2004), the 2004 academic year was the second year that learners had been exposed in Grade 9 to this learning area statement at the specific school. At this school the assessment standard relating to the national budget or Government Income includes information on direct and indirect taxes. The teacher taught on this specific section in a 40-minute class period. No specific guidelines are provided in the EMS learning area statement as the statement provides educators only with minimum standards. Taken into account that there are many more assessment areas to be covered in the EMS learning area statement this time allocation seems reasonable. It will, however, differ from school to school. The DoE does not prescribe a specific resource (textbook) but requires teachers to be familiar with the resources needed and available as they develop their programmes (DoE, 2003:7). Authors of various EMS learning area statement textbooks market their manuscripts at different schools. The teacher at this specific school used a textbook authored by Bounds, Maila, Rall and Tonetti as a basis for developing the lesson plan relating to the effect of the national budget on the economy. The content of this textbook relating to this assessment standard is analysed in Table 4 and 5. Taking the discussion of the components of a good curriculum into account, a number of shortcomings in certain areas have been identified and are highlighted in these tables.

Table 4: Discussion and comments on the direct taxes section of Bounds (Maila, Rall \& Tonetti, 2001:56-57)

The objective for the learners is to understand why tax is important and to identify direct taxes. Comment: No comments.

A brief historic discussion explains why it is necessary to pay tax.

Comment: No comments.

The learners have to indicate by using a flow chart how tax money flows from the consumer to the government and back to the consumer.

Comment: Firstly, to obtain the best tax knowledge learners should be exposed to the correct tax terminology. This terminology determines the basis for understanding concepts in a certain context. In the direct taxes section learners are asked to create a flow chart to indicate how tax money is flowing from the consumer to the government and back to the consumer (Bounds, Maila, Rall \& Tonetti, 2001:56). Direct taxes, however, are raised on persons (Huxham \& Haupt, 2005:1) and these taxes are based on the income of such a person (Huxham \& Haupt, 2005:1). Indirect taxes refers to tax raised on transactions rather than on persons and an example of such an indirect tax is consumption tax which usually takes the form of a sales tax (GST) or a value-added tax (VAT) (Huxham \& Haupt, 2005:1). South Africa used GST before 1991. Under this system, sales to the end consumer were subject to tax which was a percentage of the sales price (Huxham \& Haupt, 2005:5). VAT is an indirect system of tax introduced on 29 September 1991, replacing the GST system. Therefore, in the context of direct taxes, persons - defined as 
natural persons, trusts, deceased estates and legal entities (Arendse, Jordaan, Kolitz \& Steyn, 2000:3) - is the correct term and not consumer, defined by the Collins Paperback Thesaurus ( $2^{\text {nd }}$ edition) as a buyer or user of commodities or one who consumes.

This activity can be difficult for learners. An example of a flow chart should rather be provided. The learners then have to research the definitions of tax, tax evasion, tax avoidance, a tax haven, tax deductible, SITE and PAYE, using any form of reference.

Comment: A dictionary is mentioned as the main source that should be used by learners. The Act is not mentioned as a source that could be used. The Act is the primary source of tax legislation and should be used by learners.

Direct taxes are defined as taxes which are raised at the source where the income is earned. Examples of this type of tax are income tax and company tax.

Comment: Company tax has no stipulated definition in the Act of 1962, it is merely income tax on companies and the way in which the term is used in the prescribed literature is incorrect. Income tax is then defined as tax that is raised on money earned by all the employees in the formal sector.

Comment: Income tax or normal tax is the most common form of tax and normal tax is calculated according to a taxpayer's taxable income (Huxham \& Haupt, 2005:5). The Income Tax Act does not mention that tax is raised from people working only in the formal sector, but all persons could be subjected to tax. This definition is a misrepresentation of who is obliged to pay tax. Also, there is no indication of when income is subject to tax.

Furthermore, the prescribed text states that a part of employees' salary is deducted and paid to the State.

Comment: The amount that is deducted is not defined as tax and could be confused with the unemployment insurance contribution or skills development levy.

An illustration of the tax tables is then used to demonstrate the calculation of the deduction.

Comment: The tax table that is used is not representative of the current tax rates. Learners are also not taught on the relevance of the concepts, for example, employee's tax deducted forms a prepayment of taxes.

In this section it is also mentioned that taxpayers receive rebates for certain expenses.

Comment: Taxable income is calculated by deducting certain expenses from gross income (Section 1 of the Act); therefore, in order to determine a taxpayers' taxable income, certain expenses may be deducted. However, Bounds, Maila, Rall and Tonetti (2001:57) state that taxpayers receive rebates for certain expenses, which implies that the rebates influence the taxable income. This is incorrect, since rebates only occur after tax has been calculated, and do not lessen taxable income as stated.

The progressive tax system of South Africa is discussed in a manner implying that the more you earn the more you pay.

Comment: No comments. 
It is suggested that people working in the informal sector do not declare their income and therefore they do not pay tax.

Comment: This is an unsubstantiated statement since all income should be declared and is subject to tax. The only time that a person will not have a tax liability will be if the taxable income does not exceed the tax threshold.

Learners should then ask an adult how to complete tax returns.

Comment: The adult who is asked may also have limited knowledge and learners may receive incorrect or no information, which is not beneficial to the learning process.

Table 4: Discussion and comments on the indirect taxes section of Bounds (Maila, Rall \& Tonetti, 2001:58-59)

\begin{tabular}{|c|c|}
\hline Activities & Comments \\
\hline $\begin{array}{l}\text { Indirect taxes are defined as taxes, which are raised } \\
\text { on expenses and Value Added Tax (VAT), Customs } \\
\text { duty and Excise duty are three types of indirect } \\
\text { taxes that are briefly discussed in the text. }\end{array}$ & $\begin{array}{l}\text { Indirect taxes are tax raised on transactions. } \\
\text { An example of such indirect tax is tax on } \\
\text { consumption (Huxham \& Haupt, 2005:1). }\end{array}$ \\
\hline $\begin{array}{l}\text { VAT is discussed using as an example the process } \\
\text { of manufacturing furniture. The text shows how } \\
\text { value is added in different cycles of the process. In } \\
\text { each link of the production chain, tax is collected } \\
\text { for the government and part of it can be claimed } \\
\text { back. Learners are then asked to determine the } \\
\text { amount of tax due to SARS in this example, as well } \\
\text { as the claims that should be deducted from the tax } \\
\text { paid. }\end{array}$ & $\begin{array}{l}\text { This calculation could be difficult for the } \\
\text { learners. No indication is given of whether } \\
\text { amounts are inclusive or exclusive. The } \\
\text { amount due to SARS is stated as an amount } \\
\text { to be paid and not as output tax. The } \\
\text { amount claimable should also rather be } \\
\text { defined as input tax. }\end{array}$ \\
\hline $\begin{array}{l}\text { Learners are expected to know the current VAT } \\
\text { percentage and at least four products that are } \\
\text { exempt from VAT and why they are exempted. }\end{array}$ & $\begin{array}{l}\text { There is no definition or explanation of } \\
\text { why certain items are exempt from VAT. }\end{array}$ \\
\hline $\begin{array}{l}\text { A brief discussion about Customs Duty follows and } \\
\text { learners are asked to name four products that are } \\
\text { imported and four that exported. }\end{array}$ & $\begin{array}{l}\text { This type of tax is interesting, but one } \\
\text { might argue that it is not as relevant to } \\
\text { learners' everyday life as income tax and } \\
\text { VAT. Time is therefore allocated to customs } \\
\text { duty which is not immediately relevant for } \\
\text { learners. }\end{array}$ \\
\hline $\begin{array}{l}\text { Learners should then evaluate the effect of Customs } \\
\text { Duty on imported products. }\end{array}$ & As above. \\
\hline $\begin{array}{l}\text { In the text, Excise Duty is defined as a tax that is } \\
\text { raised on luxury goods rather than on necessary } \\
\text { products. }\end{array}$ & As above. \\
\hline $\begin{array}{l}\text { Learners are expected to debate the following } \\
\text { subject: Excise duty is the best way to reduce } \\
\text { spending on harmful products. }\end{array}$ & As above. \\
\hline
\end{tabular}


An optimistic conclusion regarding the current curriculum is that it is compulsory for school learners. A major shortcoming, on the other hand, is the fact that only one assessment standard in the senior phase of the EMS learning area statement deals with tax education. Finally, educators do not receive proper training in this regard or guidance from the DoE. Neither is there assistance available from SARS in this regard.

\section{Conclusion}

Peters (1991:188) found that citizens do, on the whole, like the benefits they receive from government and tend to be much more willing to pay taxes when reminded of the benefits received as a consequence of doing so. This paper indicated that the most appropriate time for tax education is at the early secondary level. It is suggested that, since the vast number of scholars are the taxpayers of the future, implementing tax education at school level should have the best chance of success. This will ensure that a large percentage of all South Africans will have the opportunity to receive some form of tax training.

From the evaluation of the education programme at school level in the USA, it became apparent that the programme is very detailed. The tax information that is provided gives American students background information on tax laws and knowledge of key terms, basic concepts and definitions. Each of the themes allows students to gain insight into how the American tax system was developed and how tax influences American citizens. Although it is not a compulsory program, it is assumed that with the high percentage of students with Internet access this programme is very successful in the USA. However, South Africa, cannot rely on the internet as source of tax training, as only a small percentage of individuals are exposed to information of the SARS website.

In evaluating the components of a good curriculum, it became evident that when implementing a tax curriculum, a variety of approaches and guidelines can be used. A tax curriculum must essentially inform learners about tax, but need not necessarily focus on in-depth knowledge of the subject. In analysing the current situation of taxation education as part of the senior phase of the EMS learning area statement at one school, a number of shortcomings in certain areas were identified:

- the use of wrong terminology

- making of unjust statements;

- learners not being taught the general rules;

- the relevance of certain concepts not being taught; and

- flow charts and case studies not being used.

From this study it can be optimistically concluded that the current curriculum is in fact compulsory for scholars. A major shortcoming, however, is the fact that only one assessment standard in the senior phase of the EMS learning area statement deals with tax education. Finally, educators do not receive proper training in this regard from the DoE and no assistance is available from SARS. It is further important to stress that an effective tax curriculum should inform scholars about tax and that it does not necessarily focus on in-depth knowledge of taxation. It is essential that the 
level of knowledge should be applicable to learners in Grade 9. The proposed curriculum should convey basic tax knowledge to school learners at an appropriate level.

From this research it is suggested that SARS works together with the South African DoE to improve the current tax curriculum in South African Schools. This will potentially ensure that an increasing number of citizens will become responsible taxpayers who understand their obligation to contribute to an improving tax compliance culture, in accordance with the professed visions of SARS (2004).

As this is only an exploratory study, it is important to point out that there might be new and more up-to-date textbooks addressing some of these issues. Further research is therefore encouraged, especially with regards to the opportunities for tax education at lower levels in the EMS learning area statement, as well as other resources available to educators. Notwithstanding these limitations, it is hoped that this article has made a contribution to the field of taxation education.

\section{References}

Arendse, J.A., Jordaan, K., Kolitz, M.A. \& Steyn, M.L. (2001). Silke: Suid-Afrikaanse Inkomstebelasting. Durban: Butterworths.

Australian Tax Office (ATO). (1998). Teaching tax with the Tax Files. (Online).

(http://www.ato.gov.au/corporate/content.asp?doc=/content/mr9807.htm). Accessed: 17 March 2004.

Bonner, S.E. (1999). Choosing teaching methods based on learning objectives: an integrative framework. Issues in Accounting Education, 14(1):11-39.

Bounds, M., Maila, E., Rall, C. \& Tonetti, R. (2001). Dinamiese Ekonomiese Bestuurswetenskappe. $1^{\text {st }}$ ed. Cape Town: Kagiso Education.

Collins Paperback Thesaurus in A-to-Z form. $2^{\text {nd }}$ edition. (1990). Glasgow: William Collins Sons.

DeBell, M. \& Chapman, C. (2003). Computer and Internet use by children and adolescents in 2001. (NCES 2004-014) U.S. Department of Education, Washington, DC: National Centre for Education Statistics.

Department of Education. (2002). Revised National Curriculum Statement Grade R-9 (Schools Policy): EMS. Pretoria: Government Printer.

Department of Education. (2003). Revised National Curriculum Statement Grade R-9: Teacher's guide for the development of learning programmes: EMS. Pretoria: Government Printer.

Department of Education. (2004). Higher Education. (Online). (http://www.education.gov.za/index.asp?src=bron8xsrc=hedu). Accessed: 30 March 2004.

Feltham, G.D. (1996). Some thoughts on teaching tax. CA Magazine, 129(5):31-35.

Flesher, T.K. \& Rescho, J.A. (1986). Tax concepts and their importance in the undergraduate curriculum. Journal of Accounting Education, 4(1):55-68.

Gore, R. \& Wong-on-Wing, B. (1998). The acquisition and transfer of tax skills. Journal of the American Taxation Association, 20(2):117-126.

Hanno, D.M. (1999). Energizing your teaching: developing a community of learning. Issues in Accounting Education, 14(2):323-335.

Hite, P. \& Hasseldine, J. (2001). A primer on tax education in the United States of America. Accounting Education, 10(1):3-13. 
Huxham, K. \& Haupt, P. (2005). Notes on South African Income Tax. $24^{\text {th }}$ edition. Roggebaai: H $\&$ H Publications.

Income Tax Act 58 of 1962.

Internal Revenue Service (IRS). (2004a). Teacher lesson plan. (Online).

(http://www.irs.gov/app/understandingtaxes/jsp/teacher_home.jsp) Accessed: 13 May 2004.

Internal Revenue Service (IRS). (2004b). VITAe ${ }^{3}$. (Online).

(http://www.irs.gov/app/understandingtaxes/jsp/cool_stuff_vita.jsp). Accessed 13 May 2004.

Jones, S.M. \& Duncan, W.A. (1995). Teaching the introductory tax course: a new paradigm. The Journal of the American Taxation Association, 17(1):95-107.

Kleiner, A., Lewis, L. \& Greene, B. (2003). Internet access in U.S. public schools and classrooms: 1994-2002. (NCES 2004-011) U.S. Department of Education, Washington, DC: National Centre for Educational Statistics.

Lewis, A. (1982). The psychology of taxation. Oxford: Martin Robertson.

Mohr, P.J., Van der Merwe, C., Botha, Z.A. \& Inggs, E.J. (1998). Die praktiese gids tot Suid-Afrikaanse ekonomiese aanwysers. Isando: Lexicon.

Nichols, N.B., Everett, J.O. \& Boley, R. (1999). Instructional resources for tax education: communicating the complexities of capital gains for individuals after the 1997 and 1998 tax acts. Accounting Education, 14(1):117-143.

Oberholzer, R. (2005). A survey of the perceptions of previously disadvantaged South Africans on taxation. Critical Perspectives on Accounting 16(3), 249-275.

Oppenheimer, J.S. (1997). The model tax curriculum-tax education for the 21st century. The Tax Adviser, 28(5):322-323.

Peters, B.G. (1991). The politics of taxation: a comparative perspective. Cambridge, Massachusetts: B. Blackwell.

Phillips, L. (2004). Responsible for taxpayers' education-Nationally at SARS. Personal communication, 4 March. Pretoria.

Psybox (2006). (Online) (http://www.psybox.com/web_dictionary/Decknowlege.htm). Accessed 22 February 2006.

Schaefer, R.T. (1989). Sociology. $3^{\text {rd }}$ ed. New York: R. R. Donnelley \& Sons.

South African Revenue Services (SARS). (1998). Tax \& the salaried worker. (Online). (http://www.sars.gov.za). Accessed 25 September 2002.

South African Revenue Services (SARS). 1999. Taxation in South Africa. (Online). (http://www.sars.gov.za). Accessed 25 September 2002.

South African Revenue Services (SARS). (2002). SARS Charters. (Online). (http://www.sars.gov.za). Accessed 13 November 2002.

South African Revenue Services (SARS). (2004). On the preliminary revenue results for the 2003/4 fiscal year ending 31 March 2004. Press Release. (Online). (http://www.sars.gov.za). Accessed 31 May 2004.

Statistics South Africa. (2001a). Census 2001. (Online). (http://www.statssa.gov.za/census2001/digiAlas/index.html). Date accessed 12 May 2004.

Statistics South Africa. (2001b). Census 2001: key results. (Online). (http://statssa.gov.za). Accessed 12 May 2004.

Weirich, I. (2004). Teacher, Eldoraigne High School. Personal communication, 12 August. Centurion. 


\section{Ruanda Oberholzer}

Department of Taxation

Economic and Management Science Faculty

University of Pretoria

Telephone: 0124204590

Fax: 0124203725

E-mail:: ruanda.oberholzer@up.ac.za

\section{Martelize Nel}

Economic and Management Science Faculty

University of Pretoria

Telephone: 0124204590

Fax: 0124203725

E-mail: martelize@sjaccountingservices.co.za 